\title{
PENGARUH KOMPENSASI, PENDIDIKAN DAN PROGRAM KESEJAHTERAAN TERHADAP PRODUKTIVITAS KERJA WARTAWAN DI PROVINSI BALI
}

\author{
Hendri Harliawan ${ }^{1}$ \\ I.G.W Murjana Yasa ${ }^{2}$ \\ Made Heny Urmila Dewi ${ }^{3}$ \\ 1,2,3 Fakultas Ekonomi dan Bisnis Universitas Udayana (Unud), Bali, Indonesia \\ email: hendrispd@yahoo.com
}

\begin{abstract}
ABSTRAK
Di Provinsi Bali persoalan produktivitas menjadi masalah tersendiri terutama dalam bidang tenaga kerja media (wartawan). Rendahnya kompensasi berupa gaji, insentif dan tunjangan sosial menjadi persoalan yang diduga mempengaruhi rendahnya produktivitas kerja. Karena itu, penelitian ini bertujuan menganalisis pengaruh; (1) kompensasi dan pendidikan terhadap program kesejahteraan wartawan, (2) kompensasi, pendidikan, pengalaman kerja dan program kesejahteraan terhadap produktivitas kerja, (3) pendidikan terhadap kompensasi, (4) pengaruh tidak langsung pendidikan terhadap program kesejahteraan (5) pengaruh tidak langsung kompensasi dan pendidikan terhadap produktivitas kerja, dan (6) pengaruh pendidikan terhadap produktivitas kerja yang dimoderasi pengalaman kerja wartawan di Provinsi Bali.

Kata Kunci: Kompensasi, Pendidikan, Program Kesejahteraan, Pengalaman Kerja, Produktivitas
\end{abstract}

\begin{abstract}
In the province of Bali productivity issues become a problem in itself, especially in the field of journalists. The low compensation in the form of salaries, incentives and social benefits to be subject suspected to affect the low productivity of labor. Therefore, purpose this study to analyze the influence; (1) compensation and education for the employee's well-being of journalists, (2) compensation, education, work experience and employee's well-being on work productivity, (3) the effect education to compensation, (4) the indirect effect of education on welfare (5) the indirect effect of compensation and education to work productivity, and (6) the effect moderated work experience to influence education on journalist productivity in Bali.
\end{abstract}

Keywords: Compensation, Education, Well-being, Work Experience, Productivity 


\section{PENDAHULUAN}

\section{Latar Belakang}

Kenyataan perubahan zaman yang terus melangkah maju dengan segala perkembangannya menjadi tantangan tersendiri bagi belahan dunia manapun terutama negara berkembang. Di pedalaman sekalipun sedikit demi sedikit akan mulai terbuka dan berhubungan dengan dunia luar serta budaya yang lebih modern, sehingga akan menciptakan pola kehidupan dan kebutuhan yang baru bagi masyarakat. Proses tersebut pun dipastikan akan berlangsung lebih gencar lagi pada tahun-tahun yang akan datang (Todaro dan Smith, 2006).

Entitas negara yang tidak siap mengikuti perkembangan tersebut, secara otomatis akan jauh tertinggal dari negara lain yang sudah siap berkompetisi. Sehingga, bagi negara manapun di dunia ini, harus siap menerima segala perubahan yang terus berkembang dari waktu ke waktu. Karena, persaingan dalam beberapa waktu mendatang menyangkut bagaimana suatu negara bisa mengelola perekonomiannya ke arah yang lebih maju, efisien, serta produktif. Oleh karena itu, untuk memperkecil segala bentuk persoalan yang muncul akibat perubahan yang terjadi, pemerintah dalam suatu negara harus hadir sebagai kontrol atas sumber daya yang dimiliki.

Dalam konteks bernegara, perubahan pola kehidupan masyarakat tersebut akan mempermudah pemerintah menentukan arah pembangunan ekonomi yang diharapkan, pembangunan ekonomi ini diarahkan untuk mencapai kemakmuran dan kesejahteraan bagi seluruh rakyatnya. Hanya saja, untuk mencapai hal tersebut bukan persoalan mudah, karena akan berhadapan dengan masalah- 
masalah pokok seperti ketenagakerjaan, pengangguran, ketimpangan distribusi pendapatan, kemiskinan serta ketidakseimbangan ekonomi (Lestariningsih, 2006). Di Indonesia, persoalan-persoalan pokok di atas masih menjadi masalah yang belum mampu diselesaikan pemerintah, terutama mengenai tenaga kerja. Padahal menurut Sukirno, (2008), salah satu tujuan penting dalam pembangunan ekonomi adalah penyediaan lapangan kerja yang cukup untuk mengejar pertumbuhan angkatan kerja yang pada akhirnya mendorong pertumbuhan ekonomi. Oleh karena itu, sangat wajar negara berkembang seperti Indonesia harus mulai memperhatikan sumber daya manusia yang dimilikinya, karena fakta sampai hari ini, Indonesia masih mengandalkan sumber daya manusia sebagai faktor penunjang di berbagai sektor industri.

Tantangan utama yang dihadapi industri nasional secara umum saat ini adalah kecenderungan penurunan daya saing industri di tingkat pasar, yang disebabkan oleh antara lain meningkatnya biaya energi, pengeluaran tinggi, belum memadainya tuntutan operasional, serta seringkali sektor industri tidak mampu menciptakan tenaga yang produktif akibat dari komitmen perusahaan kepada pekerja yang masih lemah, (Idris, dkk, 2007). Padahal menurut Le Grain, (2003) produktivitas pekerja menjadi salah satu faktor penentu keberhasilan sebuah perusahaan dalam mencapai tujuan produksinya. Tidak hanya itu, pentingnya produktivitas dalam kegiatan perekonomian juga menjadi penunjang untuk sebuah kemajuan, apalagi produktivitas selama ini menjadi salah satu elemen paling mudah untuk mengukur keberhasilan kegiatan ekonomi. 
Produktivitas kerja, menjadi salah satu aspek penting dalam sebuah perusahaan dalam menentukan kelangsungan usaha di masa depan. Dua aspek penting yang perlu diperhatikan perusahaan dari produktivitas adalah efesiensi yang berkaitan dengan berbagai masukan perusahaan dan pekerjaan serta efektifitas yang berkaitan dengan suatu kenyataan dan hasil-hasil yang diharapkan untuk dapat tercapai dengan baik. Oleh sebab itu, produktivitas kerja sangat tergantung dari sumber daya manusia yang bekerja dan memiliki ruang lingkup yang lebih baik. Sebagaimana doktrin pada konferensi Oslo 1984 yang dikutip Sinungan (2000) menyatakan bahwa "Produktivitas merupakan sebuah konsep universal yang bertujuan menyediakan lebih banyak lagi barang dan jasa untuk lebih banyak manusia, dengan catatan menggunakan sumber-sumber riil yang semakin sedikit”.

Mengenai media massa di Bali, sejak disahkannya Undang-Undang Nomor 40 Tahun 1999 tentang Pers, Perusahaan Media oleh Dewan Pers digolongkan menjadi perusahaan industri dalam menyediakan informasi bagi publik, karena memproduksi berita yang kemudian dijual kepada publik dalam bentuk cetak maupun elektronik. Hal tersebut memiliki arti bahwa, perusahaan media juga kemudian memiliki tujuan untuk memperoleh keuntungan dari hasil penjualan artikel berita cetak maupun elektronik tersebut. Oleh karena itu, untuk mencapai tujuan itu, maka perusahaan media membutuhkan tenaga kerja professional untuk kepentingan mencari berita, memproduksi dan mempublikasinya. 
Profesionalitas dari pekerja media di Provinsi Bali dalam urusan dengan perusahaan media, tidak sebatas hubungan searah, melainkan juga hubungan timbal balik yang dapat saling menguntungkan. Perusahaan media di Bali mempunyai tujuan mencapai target produksi berita melalui pekerja media atau wartawan dalam periode tertentu, di sisi yang lain wartawan juga memiliki hakhak yang melekat dalam status kewartawanannya, yang harus dipenuhi perusahaan media massa (Undang-Undang Nomor 40 tahun 1999 tentang Pers). Selain amanat Undang-Undang di atas, Undang-Undang Nomor 3 Tahun 2014 tentang Perindustrian juga mengamanatkan dan mewajibkan industri mengembangkan sumber daya manusia yang dimilikinya, termasuk hak yang meski diterima dari wartawan tersebut dalam mencapai kesejahteraan hidupnya.

Undang-Undang Nomor 13 Tahun 2003 tentang Ketenagakerjaan juga secara tegas mengamanatkan bahkan, perusahaan berkewajiban memberikan hak sepenuhnya kepada tenaga kerja, baik soal kesejahteraan tenaga kerja, tunjangan sosial, insentif, tunjangan hari raya, waktu kerja, dan beberapa penekanan lainnya. Penelitian Ajala (2012), memperkuat pernyataan peraturan perundangan di atas, bahwa kebijakan perusahaan mengedepankan kesejahteraan wartawan menjadi relevan untuk meningkatkan kinerja maupun produktivitas pekerja. Selain itu, penelitian Tiwari (2014), mengemukakan bahwa, pemberian kesejahteraan oleh perusahaan seperti gaji, tunjangan, insentif bermanfaat untuk kehidupan seharihari karyawan seperti menjaga kesehatan dan pemeliharaan fisik lainnya dalam rangka menunjang aktivitas pekerja disaat bekerja, yang akhirnya mendorong terciptanya produktivitas yang tinggi baik dalam konteks organisasi maupun 
individu pekerja sendiri. Sehingga dalam penelitian ini, dikemukakan bahwa, kesejahteraan pekerja menjadi faktor pendorong terciptanya produktivitas pekerja.

Menurut rilis Dewan Pers Nasional, (2015), di Indonesia pasca reformasi dan terbitnya undang-undang pers, jumlah perusahaan media semakin banyak. Namun, tidak sedikit pula yang akhirnya gulung tikar mengalami kerugian, karena tidak lagi produktif dalam mengemas berita yang menarik bagi pembaca. Di Provinsi Bali keadaan hampir serupa, baik perusahaan media cetak, elektronik, maupun siber/online jumlahnya semakin banyak. Hanya saja, di Bali tumbuh kembangnya perusahaan media dan penyerapan tenaga kerja untuk wartawan atau tenaga peliput berita lebih stabil. Berdasarkan data Dewan Pers Nasional tahun 2015, perusahaan media dan jenis media di Provinsi Bali dapat dijelaskan dalam Tabel 1.1 berikut.

Tabel 1.

Perusahaan Media Yang Berbadan Hukum di Provinsi Bali Tahun 2015

\begin{tabular}{llccccc}
\hline No & Jenis Media & Harian & Mingguan & Bulanan & Jumlah & $\begin{array}{c}\text { Jumlah } \\
\text { Wartawan } \\
\text { (Orang) }\end{array}$ \\
\hline 1 & Cetak & 12 & 2 & 2 & 16 & 187 \\
2 & Televisi & 14 & - & - & 14 & 45 \\
3 & Radio & 60 & - & - & 60 & 30 \\
4 & Siber/Online & 6 & - & - & 6 & 89 \\
\hline Jumlah & $\mathbf{9 2}$ & $\mathbf{2}$ & $\mathbf{2}$ & $\mathbf{9 6}$ & $\mathbf{3 5 1}$ \\
\hline
\end{tabular}

Sumber: Dewan Pers Nasional, AJI Denpasar, dan PWI Provinsi Bali (2015)

Berdasarkan data dari Tabel 1. tersebut, jika melihat dari jumlah perusahaan media di Bali cukup banyak mencapai 96 perusahaan media, radio mendominasi, dan pada urutan kedua ditempati posisi perusahaan media cetak, posisi tiga dan empat ditempati secara berurutan oleh perusahaan media Televisi dan Siber/Online. Lebih diperjelas lagi, untuk perusahaan media lokal dari data Dewan Pers Nasional hanya tercatat 80 perusahaan media, sementara 16 
perusahaan media lainnya merupakan perusahaan media nasional. Sementara itu, jumlah tenaga kerja wartawan media massa berdasarkan data dari Persatuan Wartawan Indonesia (PWI) Bali dan Aliansi Jurnalis Independen (AJI) Denpasar tahun 2015 tercatat mencapai 351 orang wartawan. Jumlah wartawan tersebut berasal dari perusahaan media cetak, elektronik, maupun ciber/online. Wartawan media cetak mendominasi jumlah wartawan di Provinsi Bali, yakni mencapai 187 orang, wartawan media televisi (TV) 45 orang, wartawan dari media siber/online 30 orang, sedangkan 89 orang lainnya adalah wartawan radio yang tersebar di semua daerah dari berbagai perusahaan.

Jika dilihat fakta di lapangan dari berbagai jenis perusahaan media tersebut, cara kerja dan prosedur peliputan berita oleh wartawan sampai pada masuknya berita ke dapur redaksi perusahaan memiliki kesamaan satu dengan lainnya. Hanya saja, kebijakan pengupahan/penggajian, pemberian insentif, tambahan upah kelebihan kerja (lembur), termasuk juga pemberian tunjangan sosial berbeda satu perusahaan dengan perusahaan lainnya. Sehingga disinyalir, dalam hal ini setiap wartawan dari berbagai jenis media memiliki tingkat kesejahteraan maupun produktivitas yang berbeda pula. Jika demikian, maka akan menjadi temuan baru dalam menganalisis lebih lanjut fenomena tersebut.

Tuntutan wartawan untuk lebih produktivitas menghasilkan berita, hampir sama ditekankan oleh perusahaan media manapun, baik perusahaan media cetak, elektronik/televisi, siber/online maupun radio, yang pada gilirannya akan menggiring perusahaan media kearah yang lebih baik. 
Tuntutan produktivitas yang diwajibkan perusahaan media kepada wartawan idealnya mempunyai hubungan timbal balik. Perusahaan media memberikan hak kepada wartawan, dan pada gilirannya wartawan juga akan memaksimalkan produktivitas. Hal ini ditekankan sebanding dengan pekerjaan wartawan yang memiliki resiko cukup tinggi dibandingkan pekerjaan lainnya, disebabkan mobilitas wartawan yang cukup tinggi dalam mencari berita di lapangan serta setiap hari menantang berbagai bentuk resiko dalam bekerja. Tidak hanya itu, pekerjaan wartawan adalah pekerjaan yang tidak beraturan baik dari segi tugas, cara bekerja, dan dari segi pengupahan (Witschge dan Nygren, 2009). Menurut Balaji (2013) dalam penelitian yang tertuang dalam sebuah jurnal internasional mengungkapkan bahwa, kesejahteraan pekerja menjadi amat penting dalam mempengaruhi produktivitas pekerja. Hasil penelitiannya menunjukkan bahwa, pada kasus tertentu dalam situasi persaingan banyak di antara perusahaan yang memberikan kesejahteraan penuh kepada pekerjanya untuk pencapaian profesionalitas dan produktivitas pekerjanya.

Banyak faktor yang mengakibatkan produktivitas pekerja rendah atau mengalami penurunan, antara lain salah satunya menyangkut pemberian kompensasi, tingkat pendidikan, pengalaman kerja dan kesejahteraan yang diberikan perusahaan kepada karyawannya. Menurut Dessler dalam Yuniarsih (2009), mengatakan bahwa kompensasi pegawai adalah semua bentuk penggajian atau ganjaran yang mengalir kepada pegawai atau timbul dari status kepegawaian mereka. Kompensasi juga merupakan hak yang diterima karyawan sebagai pengganti atas kontribusi yang diberikan kepada organisasi suatu perusahaan. 
Tidak hanya itu, kompensasi juga merupakan imbalan jasa atau balas jasa yang diberikan oleh perusahaan kepada para tenaga kerja, yang disebabkan oleh karena tenaga kerja tersebut telah memberikan sumbangan tenaga dan pikiran demi kemajuan perusahaan guna mencapai tujuan yang di tetapkan (Sastrohadiwiryo, 2003). Konpensasi sendiri terdiri dari upah/gaji, insentif, jaminan sosial, asuransi, bonus, tunjangan dan banyak bentuk lainnya yang merupakan hak atas pekerjaan yang telah dilakukan pekerja (Anoraga, 2005).

\section{METODE PENELITIAN}

\section{Lokasi Penelitian}

Untuk memberikan gambaran yang jelas tentang variabel dan kondisi lingkungan terkait variabel yang diteliti, maka penelitian ini berlokasi di Provinsi Bali. Dipilihnya Provinsi Bali sebagai lokasi penelitian yakni dengan pertimbangan latar belakang masalah yang sesuai dengan objek penelitian. Selain itu, pertimbangan lainnya adalah karena Provinsi Bali sebagai daerah tujuan wisata terbesar di Indonesia yang dianggap memiliki kompleksitas persoalan yang beragam. Bahkan Provinsi Bali menjadi objek penelitian yang menarik, karena pembangunannya berlangsung cukup cepat dibandingkan dengan daerah lain, sehingga banyak persoalan maupun peristiwa yang baik menjadi objek penelitian akademik.

\section{Jenis Data}

Data yang digunakan dalam penelitian ini adalah data kuantitatif dan kualitatif. Data kuantitatif dalam penelitian ini menyangkut antara lain, produktivitas, program kesejahteraan wartawan, pengalaman kerja, kompensasi, 
dan pendidikan serta jumlah perusahaan media di Provinsi Bali. Sementara data kualitatif adalah berupa dara hasil penyebaran angket, wawancara terstruktur dan mendalam yang diberikan kepada para wartawan di seluruh kabupaten/kota di Provinsi Bali.

\section{Sumber Data}

Sumber data yang digunakan adalah data primer dan sekunder. Dalam penelitian ini data primer bersumber dari responden yaitu wartawan di Provinsi Bali tentang variabel produktivitas, program kesejahteraan wartawan, pengalaman kerja, kompensasi, dan tingkat pendidikan. Sementara data sekunder adalah data mengenai jumlah wartawan, jumlah perusahaan media, dan data-data yang bersumber dari Dewan Pers Nasional, PWI Bali, dan AJI Denpasar tahun 2015.

\section{Variabel Penelitian}

Terdapat 5 variabel dalam penelitian ini yang terbagi menjadi dua jenis variabel yakni variabel dependen adalah program kesejahteraan karyawan (Y1), dan produktivitas kerja (Y2), sedangkan variabel independen terdiri dari variabel kompensasi (X1), tingkat pendidikan (X2), dan pengalaman kerja (Z).

\section{Populasi dan Sampel}

Menurut Sugiyono (2013) populasi adalah wilayah generalisasi yang terdiri dari obyek atau subyek yang mempunyai kualitas dan karakteristik tertentu yang ditetapkan oleh peneliti untuk dipelajari dan ditarik kesimpulannya. Sampel adalah bagian dari jumlah dan karakteristik yang dimiliki oleh populasi tersebut (Jogiyanto, 2007). Didalam penelitian ini populasi adalah seluruh wartawan di Provinsi Bali sebanyak 351 orang wartawan, sementara sampel dalam penelitian 
ini adalah berjumlah 99 sampel. Dalam penelitian ini, teknik pengambilan sampel responden menggunakan teknik proportionate stratified random sampling yaitu teknik untuk menentukan pengambilan sampel dari populasi yang mempunyai ciri-ciri tidak menentu (heterogen) (Sugiyono, 2013). Pada penelitian ini, strata yang diambil adalah berdasarkan status kepegawaian wartawan (tetap dan kontrak), serta jenis media wartawan yang menjadi sampel (cetak, tv, radio dan ciber/online).

\section{Definisi Identifikasi Variabel}

1. Program Kesejahteraan (Y1)

a. Tunjangan Hari Tua $\left(\mathrm{Y}_{1.1}\right)$, dengan parameter pemberian tunjangan hari tua, diukur melalui penyebaran kuisioner dengan menggunakan metode rating scale dengan skor 1-10.

b. Rasa Aman $\left(\mathrm{Y}_{1.2}\right)$ dengan dua parameter yakni perlindungan hukum perusahaan dengan pengukuran dummy (0/1), dan fasilitas tempat kerja diukur dengan metode rating scale dengan skor 1-10.

c. Kebahagiaan Karyawan $\left(\mathrm{Y}_{1.3}\right)$, dengan dua parameter yakni rekreasi karyawan dan pemberian izin dan cuti diukur dengan menggunakan metode rating scale dengan skor 1-10.

d. Kepuasan $\left(\mathrm{Y}_{1.4}\right)$ dengan tiga parameter yakni kepuasan kerja, kepuasan keluarga dan kepuasan hidup diukur dengan menggunakan metode rating scale dengan skor 1-10. 
e. Tingkat Kemakmuran $\left(\mathrm{Y}_{1.5}\right)$ dengan dua parameter yakni, bonus hari raya dan tunjangan kematian diukur dengan menggunakan metode rating scale dengan skor 1-10.

f. Fasilitas Karyawan $\left(\mathrm{Y}_{1.6}\right)$ dengan tiga parameter yakni fasilitas kesehatan, fasilitas transportasi, dan fasilitas rumah/kontrakan diukur dengan menggunakan metode rating scale dengan skor 1-10.

\section{Produktivitas (Y2)}

a. Kuantitas Kerja $\left(\mathrm{Y}_{2.1}\right)$, kuantitas kerja yang dimaksud adalah rata-rata hasil berita yang mampu ditulis seorang wartawan per hari, dinyatakan dalam satuan angka per hari.

b. Kualitas Kerja $\left(\mathrm{Y}_{2.2}\right)$, kualitas kerja yang dimaksud adalah, rata-rata berita yang naik cetak yang dihasilkan seorang wartawan per hari dikalikan dengan nilai satuan berita (Rp), dinyatakan dalam satuan rupiah (Rp)/hari.

c. Ketepatan waktu kerja $\left(\mathrm{Y}_{2.3}\right)$, ketepatan waktu kerja yang dimaksud adalah efektivitas kerja wartawan yakni efektivitas penggunaan waktu dalam pembuatan satu berita atau perbandingan antara jumlah jam kerja per hari dengan hasil berita yang didapat per hari dengan satuan (jam/berita).

\section{Kompensasi (X1)}

a. Upah/Gaji $\left(\mathrm{X}_{1.1}\right)$, upah yang dimaksud adalah total upah yang didapat selama sebulan, sementara gaji adalah gaji pokok yang didapat wartawan yang sama-sama dinyatakan dalam satuan Rupiah (Rp) per bulan.

b. Insentif $\left(\mathrm{X}_{1.2}\right)$, insentif merupakan pemberian bonus atau penghargaan oleh pimpinan perusahaan terhadap pekerja sebagai penghargaan atas prestasi 
pekerja di luar dari upah atau gaji pokok pekerja. Insentif dinyatakan dalam satuan Rupiah per bulan.

c. Jaminan Sosial $\left(\mathrm{X}_{1.3}\right)$, jaminan sosial merupakan suatu perlindungan bagi responden dalam bentuk santunan berupa uang dari perusahaan di luar upah atau gaji pokok. Jaminan sosial dinyatakan dalam satuan Rupiah per bulan.

4. Pendidikan (X2)

a. Tingkat pendidikan formal $\left(\mathrm{X}_{2.1}\right)$, adalah lama pendidikan masing-masing pekerja yang ditentukan dari tahun sukses responden menamatkan pendidikannya.

b. Kesesuaian jurusan $\left(\mathrm{X}_{2.2}\right)$, diukur dengan parameter kesesuaian jurusan dengan pekerjaan responden saat ini, diukur dengan rating scale dengan skor 1-10.

5. Pengalaman Kerja $(Z)$, dari lima indikator yakni keterampilan adaptif $\left(Z_{1}\right)$ dengan 2 parameter, keterampilan analitik $\left(\mathrm{Z}_{2}\right)$ dengan 2 parameter, keterampilan penetapan tujuan $\left(\mathrm{Z}_{3}\right)$ dengan 2 parameter, keterampilan tindakan $\left(\mathrm{Z}_{4}\right)$ dengan 2 parameter serta keterampilan penguasaan teknologi $\left(\mathrm{Z}_{5}\right)$ dengan 1 parameter, kesemuanya diukur dengan rating scale dengan skor 1-10.

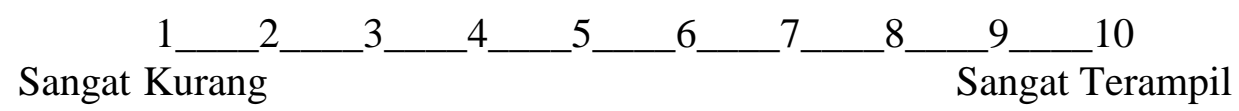

\section{Teknik Analisis Data}

Pada penelitian ini, ada dua tahap analisis yang akan dilakukan, yakni Pertama, analisis SEM dengan berbasis variance atau Component based SEM, yang juga sering disebut Partial Least Square (PLS) dengan bantuan Visual software SmartPLS (Partial Least Square) versi 3.0 yang menganalisis 
keseluruhan model dalam penelitian ini. Kedua, yakni analisis Moderated Structural Equation Modeling (MSEM) yang mengukur pengaruh variabel moderasi dengan pendekatan non linier SEM yang memungkinkan hubungan variabel independen dengan dependen yang diperkuat variabel moderasi atau disebut Moderated Structural Equation Modeling (Ghozali dan Fuad, 2005). Selanjutnya, dalam penelitian ini akan dibagi menjadi dua analisis PLS SEM yakni: (1) model pengukuran (outer model) menspesifikasikan hubungan blok indikator dengan variabel latennya; dan (2) model struktural (inner model) yang menspesifikasikan hubungan antar variabel laten.

1. Evaluasi model pengukuran (outler model)

a. Convergent validity, Convergent validity dari pengukuran model dengan indikator reflektif dapat dilihat dari korelasi antara indikator dengan variabelnya. Indikator dinilai valid jika memiliki nilai loading factor $>0,70$ untuk penelitian yang bersifat confirmatory dan nilai loading factor 0,60 0,70 untuk penelitian yang bersifat exploratory masih dapat diterima, serta nilai average variance extracted (AVE) harus > dari 0,50.

b. Discriminant validity, berhubungan dengan prinsip bahwa pengukuran (manifest variabel) konstruk yang berbeda seharusnya tidak berkorelasi dengan tinggi. Cara untuk menguji validitas discriminant dengan indikator refleksif yaitu dengan melihat nilai cross loading untuk setiap variabel harus > 0,70. Cara lain yang dapat digunakan untuk menguji validitas discriminant adalah dengan membandingkan akar kuadrat dari AVE untuk 
setiap konstruk dengan nilai korelasi antara konstruk dengan konstruk lainnya dalam model (Ghozali, 2011).

c. Composite reliability (reliabilitas gabungan), uji reliabilitas suatu konstruk dengan indikator refleksif dapat dilakukan dengan dua cara, yaitu composite reliability dan cronbach's alpha. Penggunaan cronbach's alpha untuk menguji reliabilitas konstruk akan memberikan nilai yang lebih rendah (under estimate) sehingga lebih disarankan untuk menggunakan composite reliability dalam menguji reliabilitas suatu konstruk.

2. Evaluasi model struktural (Inner model)

Dalam menilai model struktural dapat dilihat dari nilai koefisien determinasi $\left(\mathrm{R}^{2}\right)$ untuk setiap variabel laten endogen sebagai kekuatan prediksi dari model struktural. Nilai $\mathrm{R}^{2}$ merupakan uji goodness fit model. Perubahan nilai $\mathrm{R}^{2}$ digunakan untuk menjelaskan pengaruh variabel laten eksogen tertentu terhadap variabel laten endogen, apakah mempunyai pengaruh substantive. Nilai $\mathrm{R}^{2}$ (R-square) 0,$67 ; 0,33$ dan 0,19 untuk variabel laten endogen dalam model struktural yang berturut-turut menunjukkan model kuat, moderat, dan lemah (Chin dalam Ghozali, 2011). Hasil $\mathrm{R}^{2}$ mempresentasikan jumlah variance dari konstruk yang dijelaskan oleh model.

Selanjutnya evaluasi model dilakukan dengan melihat nilai signifikansi untuk mengetahui pengaruh antar variabel melalui prosedur bootstrapping atau jeckknifing. Pendekatan bootstrap merepresentasi non parametric untuk precision dari estimasi PLS. Nilai signifikansi yang digunakan yaitu: t-value 1,65 (signifikan level 10\%); 1,96 (signifikan level 5\%); dan 2,58 (signifikan level 1\%). 


\section{Moderated Structural Equation Modeling (MSEM)}

Beberapa cara untuk menguji regresi dengan variabel moderating dan salah satunya adalah Moderated Regression Analysis (MRA). MRA atau uji interaksi merupakan aplikasi khusus regresi berganda dimana dalam persamaan regresinya mengandung unsur interaksi (perkalian dua atau lebih variabel independen).

\section{HASIL DAN PEMBAHASAN}

\section{Hasil Uji PLS Outer Model}

Hasil uji PLS pada penelitian ini menggunakan evaluasi outer model dengan model reflektif pada masing-masing indikator dan evaluasi inner model menggunakan tingkat signifikansi $5 \%$. Pada penelitian ini hasil uji PLS SEM dengan bantuan softwere SmartPLS versi 3.0 secara full model dapat tersaji pada gambar 1 . bersama dengan nilai $\mathrm{R}^{2}$ masing-masing variabel lengkap dengan nilai loading masing-masing faktor. Berikut gambar full model jalur persamaan struktural.

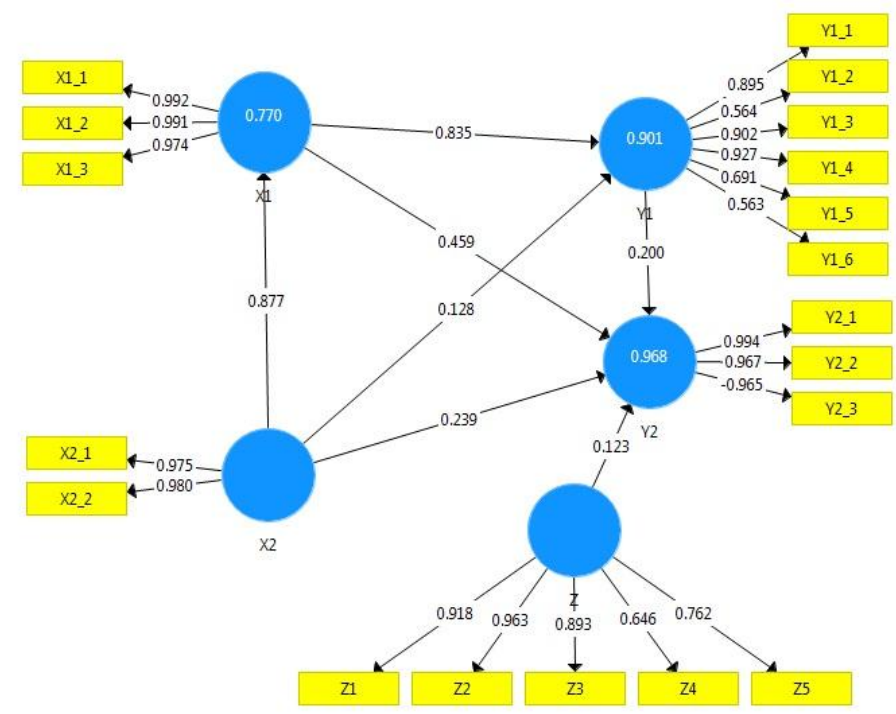

Gambar 1. Full Model Jalur Persamaan Struktural 
Hasil analisis uji model pada tahap awal menunjukkan bahwa terdapat 5 indikator variabel dengan nilai loading faktor di bawah 0,70 . Indikator tersebut adalah indikator rasa aman (Y1.2), tingkat kemakmuran (Y1.5), dan fasilitas karyawan (Y1.6) dari variabel program kesejahteraan karyawan dengan masingmasing nilai loading faktor $0,564,0,691$ dan 0,563 . Indikator lainnya adalah efektivitas kerja (Y2.3) dari variabel produktivitas kerja dengan nilai loading faktor $-0,965$ atau dengan kata lain angka yang mendekati angka nol tidak disyaratkan dimasukkan dalam model, serta nilai loading faktor action skills (Z4) dari indikator variabel pengalaman kerja yakni sebesar 0,646. Maka kelima indikator tersebut harus dikeluarkan/dieliminasi dari konstruk model yang telah disusun.

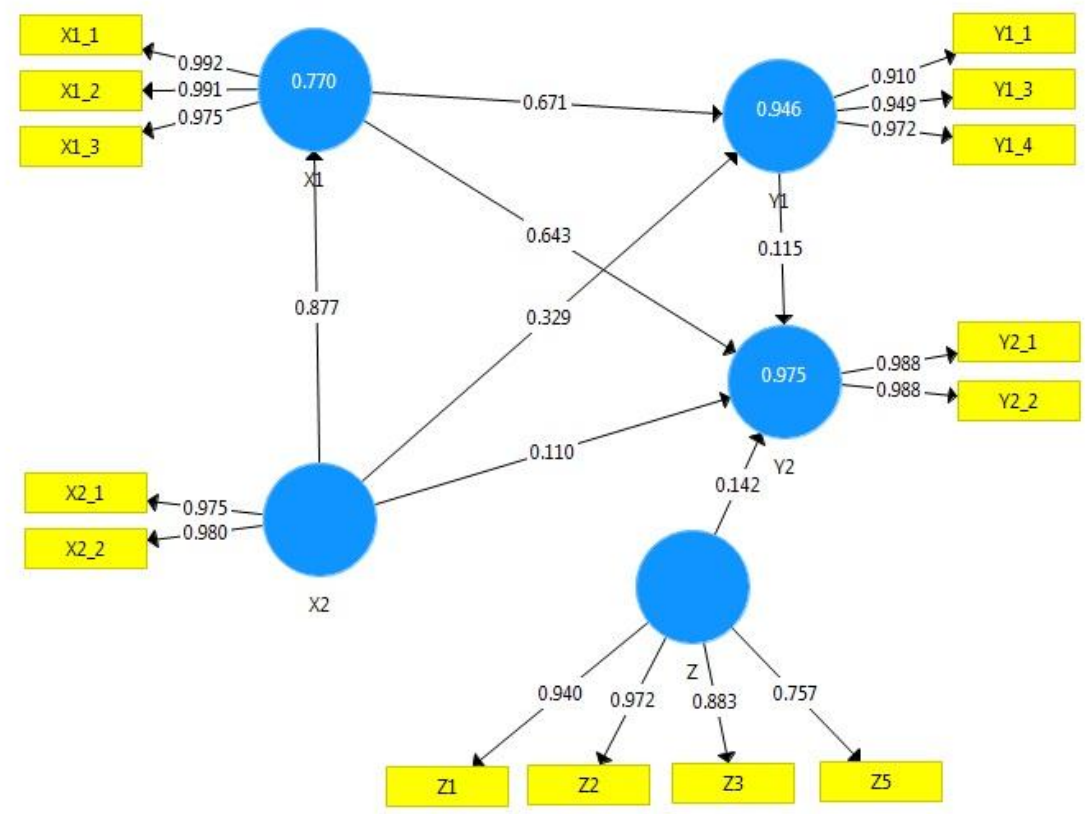

\section{Gambar 2. Full Model Jalur Persamaan Struktural (Setelah Eliminasi)}

Hasil pengujian menunjukkan bahwa semua indikator dari kontruk variabel laten pada model dinyatakan secara keseluruhan sudah memenuhi kriteria 
yang disyaratkan yakni lebih besar dari 0,70 . Selanjutnya dilakukan pengujian reliabelity dan validy konstruk yang selanjutnya bisa menjadi acuan dalam melakukan evaluasi Goodness of Fit model PLS dengan tujuan mengevaluasi outer model dan inner model.

a. Uji convergent validity

Dalam penelitian ini uji convergent validity jika dilihat dari hasil outputnya menunjukkan nilai loading faktor untuk masing-masing kontruk dari variabel penelitian seperti produktivitas, program kesejahteraan, kompensasi, pendidikan serta pengalaman kerja dinyatakan valid. Hal tersebut sesuai dengan kriteria bahwa kontruk dari variabel dinyatakan valid apabila nilai loading faktor di atas 0,70 . Untuk lebih jelasnya, dapat dilihat dalam tabel 2. sebagai berikut.

Tabel 2.

Hasil uji convergent validity (Setelah Eliminasi)

\begin{tabular}{cccccc}
\hline Indikator & $\mathbf{X 1}$ & $\mathbf{X 2}$ & $\mathbf{Y 1}$ & $\mathbf{Y 2}$ & $\mathbf{Z}$ \\
\hline $\mathbf{X 1 . 1}$ & 0,992 & & & & \\
$\mathbf{X 1 . 2}$ & 0,991 & & & & \\
$\mathbf{X 1 . 3}$ & 0,975 & & & & \\
$\mathbf{X 2 . 1}$ & & 0,975 & & & \\
$\mathbf{X 2 . 2}$ & & 0,980 & & & \\
Y1.1 & & & 0,910 & & \\
Y1.3 & & & 0,949 & & \\
Y1.4 & & & 0,972 & & \\
Y2.1 & & & & 0,988 & \\
Y2.2 & & & & 0,988 & \\
$\mathbf{Z 1}$ & & & & & 0,940 \\
$\mathbf{Z 2}$ & & & & & 0,972 \\
$\mathbf{Z 3}$ & & & & & 0,883 \\
$\mathbf{Z 5}$ & & & & & \\
\hline
\end{tabular}

Sumber: Data diolah, 2017

b. Uji Composite Reliability

Uji composite reliability seluruh variabel dinyatakan reliabel apabila nilai loading-nya diatas 0,7 . Nilai composite reliability masing-masing variabel dapat dilihat pada Tabel 3 . 
Tabel 3.

Hasil uji composite reliability

\begin{tabular}{lcc}
\hline \multicolumn{1}{c}{ Variabel } & $\begin{array}{c}\text { Composite } \\
\text { Reliability }\end{array}$ & Keterangan \\
\hline Kompensasi (X1) & 0,990 & Reliabel \\
Pendidikan (X2) & 0,977 & Reliabel \\
Program Kesejahteraan (Y1) & 0,961 & Reliabel \\
Produktivitas Kerja (Y2) & 0,988 & Reliabel \\
Pengalaman Kerja (Z) & 0,939 & Reliabel \\
\hline
\end{tabular}

Sumber: Data diolah, 2017

Berdasarkan tabel di atas, hasil composite reliability menunjukkan nilai Kompensasi sebesar 0,990>0,70, Pendidikan sebesar 0,977>0,70, Program Kesejahteraan Karyawan sebesar 0,961>0,70, Produktivitas Kerja sebesar 0,988>0,70 dan Pengalaman Kerja sebesar 0,939>0,70, yang berarti secara keseluruhan variabel yang ada dalam model dinyatakan reliabel.

c. Uji Cronbachs Alpha

Uji cronbachs alpha seluruh variabel dinyatakan reliabel apabila nilai loading-nya di atas 0,7. Nilai cronbachs alpha masing-masing variabel dapat dilihat pada tabel 4 .

Tabel 4.

Hasil uji Cronbach's Alpha

\begin{tabular}{lcc}
\hline \multicolumn{1}{c}{ Variabel } & Cronbach's Alpha & Keterangan \\
\hline Kompensasi (X1) & 0,985 & Reliabel \\
Pendidikan (X2) & 0,954 & Reliabel \\
Program Kesejahteraan (Y1) & 0,938 & Reliabel \\
Produktivitas Kerja (Y2) & 0,976 & Reliabel \\
Pengalaman Kerja (Z) & 0,913 & Reliabel \\
\hline
\end{tabular}

Sumber: Data dioleh, 2017

Hasil uji cronbachs alpha menunjukkan nilai Kompensasi sebesar 0,985,

Pendidikan sebesar 0,954, Program Kesejahteraan Karyawan sebesar 0,938, Produktivitas Kerja sebesar 0,976 dan Pengalaman Kerja sebesar 0,913 yang berarti seluruh variabel dinyatakan reliabel, sehingga pengujian dapat dilanjutkan. 


\section{d. Uji discriminant validity}

Uji discriminant validity digunakan untuk menggambarkan korelasi antara variabel yang seharusnya tidak berhubungan. Korelasi dinyatakan valid dengan nilai korelasi cross loading indikator lebih besar dari nilai korelasi variabel laten yang lainnya. Nilai loading faktor masing-masing indikator dari uji discriminant validity, dapat dilihat pada Tabel 5.

Tabel 5.

Nilai Korelasi Cross Loading

\begin{tabular}{ccccccc}
\hline & $\mathbf{X 1}$ & $\mathbf{X 2}$ & $\mathbf{Y 1}$ & $\mathbf{Y 2}$ & $\mathbf{Z}$ & Keterangan \\
\hline $\mathbf{X 1 . 1}$ & $\mathbf{0 , 9 9 2}$ & 0,872 & 0,963 & 0,982 & 0,913 & Valid \\
$\mathbf{X 1 . 2}$ & $\mathbf{0 , 9 9 1}$ & 0,871 & 0,947 & 0,977 & 0,898 & Valid \\
$\mathbf{X 1 . 3}$ & $\mathbf{0 , 9 7 5}$ & 0,851 & 0,929 & 0,940 & 0,916 & Valid \\
$\mathbf{X 2 . 1}$ & 0,802 & $\mathbf{0 , 9 7 5}$ & 0,854 & 0,841 & 0,837 & Valid \\
$\mathbf{X 2 . 2}$ & 0,908 & $\mathbf{0 , 9 8 0}$ & 0,936 & 0,928 & 0,924 & Valid \\
Y1.1 & 0,857 & 0,825 & $\mathbf{0 , 9 1 0}$ & 0,882 & 0,797 & Valid \\
Y1.3 & 0,932 & 0,876 & $\mathbf{0 , 9 4 9}$ & 0,918 & 0,925 & Valid \\
Y1.4 & 0,928 & 0,896 & $\mathbf{0 , 9 7 2}$ & 0,934 & 0,919 & Valid \\
Y2.1 & 0,955 & 0,906 & 0,952 & $\mathbf{0 , 9 8 8}$ & 0,924 & Valid \\
Y2.2 & 0,982 & 0,888 & 0,956 & $\mathbf{0 , 9 8 8}$ & 0,936 & Valid \\
$\mathbf{Z 1}$ & 0,913 & 0,905 & 0,908 & 0,936 & $\mathbf{0 , 9 4 0}$ & Valid \\
$\mathbf{Z 2}$ & 0,930 & 0,901 & 0,944 & 0,946 & $\mathbf{0 , 9 7 2}$ & Valid \\
$\mathbf{Z 3}$ & 0,738 & 0,746 & 0,738 & 0,750 & $\mathbf{0 , 8 8 3}$ & Valid \\
$\mathbf{Z 5}$ & 0,579 & 0,615 & 0,625 & 0,586 & $\mathbf{0 , 7 5 7}$ & Valid \\
\hline
\end{tabular}

Sumber: Data diolah, 2017

Berdasarkan Tabel 5. uji discriminant validity menunjukkan nilai korelasi loading indikator Kompensasi, Pendidikan, Program Kesejahteraan Karyawan, Produktivitas Kerja, dan Pengalaman kerja memiliki nilai yang lebih besar dibandingkan dengan nilai korelasi cross loading variabel laten lainnya.

e. Uji Average Variance Extracted (AVE)

Nilai AVE seluruh variabel dinyatakan valid apabila nilai AVE berkisar di atas 0,50. Nilai AVE masing-masing variabel dapat dilihat pada Tabel 6. 
Tabel 6.

Hasil uji Average Variance Extracted (AVE)

\begin{tabular}{lcc}
\hline \multicolumn{1}{c}{ Variabel } & AVE & Keterangan \\
\hline Kompensasi (X1) & 0,972 & Valid \\
Pendidikan (X2) & 0,956 & Valid \\
Program Kesejahteraan Karyawan (Y1) & 0,891 & Valid \\
Produktivitas Kerja (Y2) & 0,977 & Valid \\
Pengalaman Kerja (Z) & 0,795 & Valid \\
\hline
\end{tabular}

Sumber: Data diolah, 2017

Hasil uji AVE berdasarkan tabel 6. menunjukkan bahwa secara keseluruhan AVE masing-masing variabel yang ada dalam model dinyatakan valid. Secara berurutan dari Kompensasi (X1), Pendidikan (X2), Program Kesejahteraan Karyawan (Y1), Produktivitas Kerja (Y2), dan Pengalaman Kerja (Z) mempunyai nilai AVE sebesar 0,$972 ; 0,956 ; 0,891 ; 0,977$ dan 0,795 rata-rata lebih besar dari 0,50 seperti yang disyaratkan.

\section{Hasil Uji PLS Inner Model}

Pengujian Inner model dilakukan untuk menunjukkan hubungan antar variabel laten yang diteliti. Evaluasi inner model dengan uji bootstrapping menghasilkan koefisien determinasi R-square, Q-square, path coefficients dan latent variable correlations.

a. Koefisien determinasi R-square $\left(\mathrm{R}^{2}\right)$

Hasil koefisien determinasi $\mathrm{R}^{2}$ dari model di atas dapat dilihat secara lengkap pada Tabel 7.

Tabel 7.

Koefisien Determinasi $\mathbf{R}^{2}$

\begin{tabular}{lcc}
\hline \multicolumn{1}{c}{ Variabel } & $\mathbf{R}^{2}$ & Keterangan \\
\hline Kompensasi (X1) & 0,770 & Kuat \\
Program Kesejahteraan Karyawan (Y1) & 0,946 & Kuat \\
Produktivitas Kerja (Y2) & 0,975 & Kuat \\
\hline
\end{tabular}

Sumber: Data dioleh, 2017 
Koefisien determinasi $\mathrm{R}^{2}$ pada tabel di atas menunjukkan bahwa variabel kompensasi (X1), program kesejahteraan karyawan (Y1), serta produktivitas kerja (Y2), sama-sama memiliki tingkat goodness of fit yang kuat. Sehingga secara keseluruhan variabel eksogen yang dihipotesiskan dalam persamaan mampu menjelaskan variabel endogen dengan kategori kuat.

b. Q-Square $\left(\mathrm{Q}^{2}\right)$

$Q^{2}$ mengukur seberapa baik nilai observasi dihasilkan oleh model dan juga estimasi parameternya. Suatu model dianggap mempunyai nilai predictive yang relevan jika nilai $\mathrm{Q}^{2}$ lebih besar dari 0 (nol). Besaran $\mathrm{Q}^{2}$ memiliki nilai dengan rentang $0<\mathrm{Q}^{2}<1$, model semakin baik jika nilai $\mathrm{Q}^{2}$ mendekati 1. Nilai predictive relevance diperoleh dari:

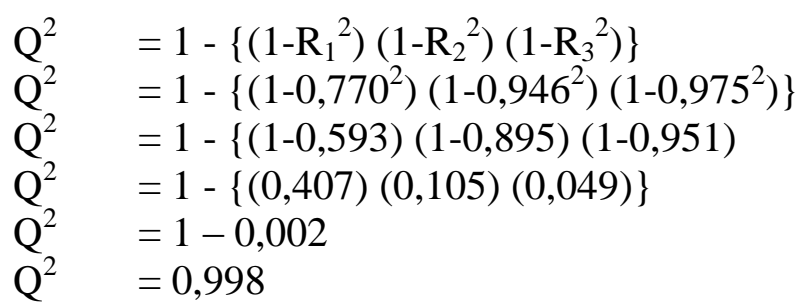

Nilai $Q$-Square dari model penelitian adalah sebesar 0,998 yang berarti bahwa model penelitian memiliki kapabilitas prediksi yang besar dalam menjelaskan variabel dependen dan model persamaan struktural yang dikembangkan dalam penelitian ini.

\section{Uji Pengaruh Langsung}

Variabel independen pada tingkat signifikansi 5\%. Hasil uji pengaruh langsung masing-masing variabel dapat dilihat pada Tabel 8. 
Tabel 8.

Pengaruh Langsung Variabel Laten

\begin{tabular}{cccccc}
\hline $\begin{array}{c}\text { Hubungan } \\
\text { Antar } \\
\text { Variebel }\end{array}$ & $\begin{array}{c}\text { Original } \\
\text { Sample }(\boldsymbol{O})\end{array}$ & $\begin{array}{c}\text { Standard } \\
\text { Deviation } \\
(\text { STDEV })\end{array}$ & $\begin{array}{c}\boldsymbol{t} \text {-Statistik } \\
(\mid \text { O/STDEV })\end{array}$ & $\boldsymbol{p}$-Values & Keterangan \\
\hline X1->Y1 & 0,671 & 0,045 & 14,874 & 0,000 & Signifikan \\
X1->Y2 & 0,459 & 0,086 & 5,332 & 0,000 & Signifikan \\
X2->X1 & 0,877 & 0,022 & 39,467 & 0,000 & Signifikan \\
X2->Y1 & 0,329 & 0,046 & 7,105 & 0,000 & Signifikan \\
X2->Y2 & 0,081 & 0,051 & 1,593 & 0,112 & Tidak Signifikan \\
Y1->Y2 & 0,236 & 0,084 & 2,812 & 0,005 & Signifikan \\
Z->Y2 & 0,247 & 0,054 & 4,602 & 0,000 & Signifikan \\
\hline
\end{tabular}

Sumber: Data diolah, 2017

a. Kompensasi terhadap Program Kesejahteraan

Hasil analisis pada tabel di atas menunjukkan bahwa kompensasi terhadap program kesejahteraan memiliki nilai koefisien positif sebesar 0,671 , dengan nilai t-statistik sebesar 14,874 dan tingkat signifikansi 0,000. Hal ini berarti bahwa kompensasi berpengaruh positif dan signifikan terhadap program kesejahteraan. Sejalan dengan penelitian Maduka and Okafor (2014) yang menyatakan bahwa, kompensasi berupa insentif maupun tunjangan akan mendorong terciptanya penghidupan yang baik bagi karyawan (program kesejahteraan). Penelitian Daft (2000); Jianhong dan Jiansuo (2012); dan Negash et al., (2014); juga mengungkapkan hal yang sama yakni pemberian kompensasi dari organisasi perusahaan mempunyai pengaruh terhadap kesejahteraan karyawan.

b. Kompensasi terhadap Produktivitas Kerja

Hasil koefesien analisis menunjukkan bahwa kompensasi terhadap produktivitas kerja memiliki nilai koefisien positif sebesar 0,459 , dengan nilai tstatistik sebesar 5,332 dan tingkat signifikansi 0,000. Hal ini berarti bahwa 
kompensasi berpengaruh terhadap produktivitas kerja. Hasil di atas sejalan dengan penelitian Ruby (2012); Yamoah (2013); dan Sulaeman (2014) memiliki hasil analisis yang sama bahwa kompensasi mempunyai hubungan yang erat dengan performa (produktivitas) karyawan.

c. Pendidikan terhadap Kompensasi

Hasil uji bootstraping menunjukkan bahwa pendidikan terhadap kompensasi mempunyai hubungan erat dibuktikan dengan nilai koefesien outputnya adalah 0,877 dengan t-statistik 39,467 taraf signifikansi 0,000. Menurut penelitian Anggraini (2012) serta Yanthi dan Marhaeni (2015) bahwa, pendidikan mempunyai hubungan erat dengan tingkat upah. Artinya dari penelitian tersebut upah sebagai kompenen kompensasi ditentukan berdasarkan tingkat pendidikan.

d. Pendidikan terhadap Program Kesejahteraan

Melihat hasil analisis pengaruh pendidikan terhadap program kesejahteraan menunjukkan bahwa, nilai koefesien sebesar 0,329 nilai t-statistik 7,105 dengan taraf siginifikansi 0,000. Hal ini berarti bahwa, pendidikan berpengaruh positif dan signifikan terhadap program kesejahteraan karyawan. Hui Min et al., (2012); Muinah (2015); dan Singh (2015) mengungkapkan bahwa pendidikan memiliki hubungan yang erat dan signifikan terhadap kesejahteraan karyawan.

e. Pendidikan terhadap Produktivitas Kerja

Data outpul SmartPLS menunjukkan bahwa nilai koefesien pengaruh pendidikan terhadap produktivitas kerja adalah 0,081 nilai t-statistif 1,593 dengan taraf signifikansi 0,112. Pada pengujian ini, dapat dinyatakan bahwa pendidikan 
tidak berpengaruh terhadap produktivitas kerja dengan nilai koefesien hanya sebesar 0,081. Nilai t-statistik 1,593 lebih kecil dari t-tabel 1,984, yang artinya pendidikan tidak berpengaruh terhadap produktivitas kerja wartawan di Provinsi Bali. Sejalan dengan penelitian Padma Dewi dan Mustika (2015) yang mengungkapkan bahwa tingkat pendidikan tidak berpengaruh signifikan terhadap produktivitas, dikarenakan tingkat pendidikan hanya bentuk formal pada saat melamar pekerjaan.

\section{f. Program Kesejahteraan terhadap Produktivitas Kerja}

Hasil uji Bootstraping menunjukkan bahwa nilai koefesien pengaruh program kesejahteraan terhadap produktivitas kerja adalah sebesar 0,236 nilai tstatistif 2,812 dengan taraf signifikansi 0,005. Pada pengujian ini, dapat dinyatakan bahwa program kesejahteraan berpengaruh positif dan signifikan terhadap produktivitas kerja. Hasil penelitian Upadhyay and Gupta (2012); Mubasher et.,al (2013); dan Olufunmilayo and Kola (2014) mengungkapkan hal yang sama bahwa, program kesejahteraan karyawan yang diberikan perusahaan menjadi faktor penting dalam mendorong tingkat produktivitas karyawan.

g. Pengalaman Kerja terhadap Produktivitas Kerja

Data outpul Bootstraping SmartPLS menunjukkan bahwa nilai koefesien pengaruh pengalaman kerja terhadap produktivitas kerja adalah sebesar 0,247 nilai t-statistif 4,602 dengan taraf signifikansi 0,000. Pada pengujian ini, dapat disimpulkan bahwa pengalaman kerja berpengaruh positif dan signifikan terhadap produktivitas kerja. 


\section{Uji Pengaruh Tidak Langsung}

Hasil uji pengaruh tidak langsung variabel laten, dapat dilihat pada Tabel 9. sebagai berikut:

Tabel 9.

Pengaruh Tidak Langsung Variabel Laten

\begin{tabular}{cccccc}
\hline $\begin{array}{c}\text { Hubungan Antar } \\
\text { Variabel }\end{array}$ & $\begin{array}{c}\text { Original } \\
\text { Sample }(\boldsymbol{O})\end{array}$ & $\begin{array}{c}\text { Standard } \\
\text { Deviation } \\
\text { (STDEV })\end{array}$ & $\begin{array}{c}\boldsymbol{t} \text {-Statistik } \\
(|\boldsymbol{O} / \mathbf{S T D E} \boldsymbol{V}|)\end{array}$ & $\boldsymbol{p}$-Values & Keterangan \\
\hline X1->Y2 Melalui Y1 & 0,158 & 0,056 & 2,819 & 0,005 & Signifikan \\
X2->Y1 Melalui X1 & 0,589 & 0,037 & 15,805 & 0,000 & Signifikan \\
X2->Y2 Melalui Y1 & 0,619 & 0,055 & 11,356 & 0,000 & Signifikan \\
\hline Sumber: Data diolah, 2017 & & & &
\end{tabular}

a. Pengaruh Tidak Langsung Kompensasi Terhadap Produktivitas Kerja

Uji Bootstraping menunjukkan bahwa, pengaruh tidak langsung kompensasi terhadap produktivitas kerja melalui program kesejahteraan sebesar 0,158 dengan t-statistik 2,819 dan p-values 0,005. Artinya kompensasi mempunyai pengaruh tidak langsung terhadap produktivitas kerja melalui program kesejahteraan.

b. Pengaruh Tidak Langsung Pendidikan Terhadap Program Kesejahteraan

Hasil di atas menunjukkan bahwa nilai pengaruh tidak langsung pendidikan terhadap program kesejahteraan adalah sebesar 0,589 dengan tstatistik 15,805 dan p-values 0,000. Dengan demikian, pendidikan mempunyai pengaruh tidak langsung terhadap program kesejahteraan melalui kompensasi.

c. Pengaruh Tidak Langsung Pendidikan Terhadap Produktivitas Kerja 
Uji Bootstraping menunjukkan bahwa pengaruh tidak langsung pendidikan terhadap produktivitas kerja adalah sebesar 0,619 dengan t-statistik 11,356 dan p-values 0,000. Maka dapat disimpulkan bahwa, pendidikan mempunyai pengaruh tidak langsung terhadap produktivitas kerja melalui program kesejahteraan. Jika melihat pengaruh langsung maupun pengaruh tidak langsung, terjadi perbedaan yang mendasar pada hubungan pengaruh variabel pendidikan terhadap produktivitas, sebab pada pengaruh langsung pendidikan tidak berpengaruh terhadap produktivitas, sementara pada pengaruh tidak langsung pendidikan terhadap produktivitas yang dimediasi oleh program kesejahteraan memiliki pengaruh yang signifikan. Artinya bahwa, terjadi mediasi penuh kedua variabel ini yang dimediasi penuh oleh variabel program kesejahteraan.

\section{Uji Pengaruh Moderasi Pengalaman Kerja}

Hasil uji pengaruh moderasi secara lengkap dapat dilihat pada Gambar 3. sebagai berikut. 


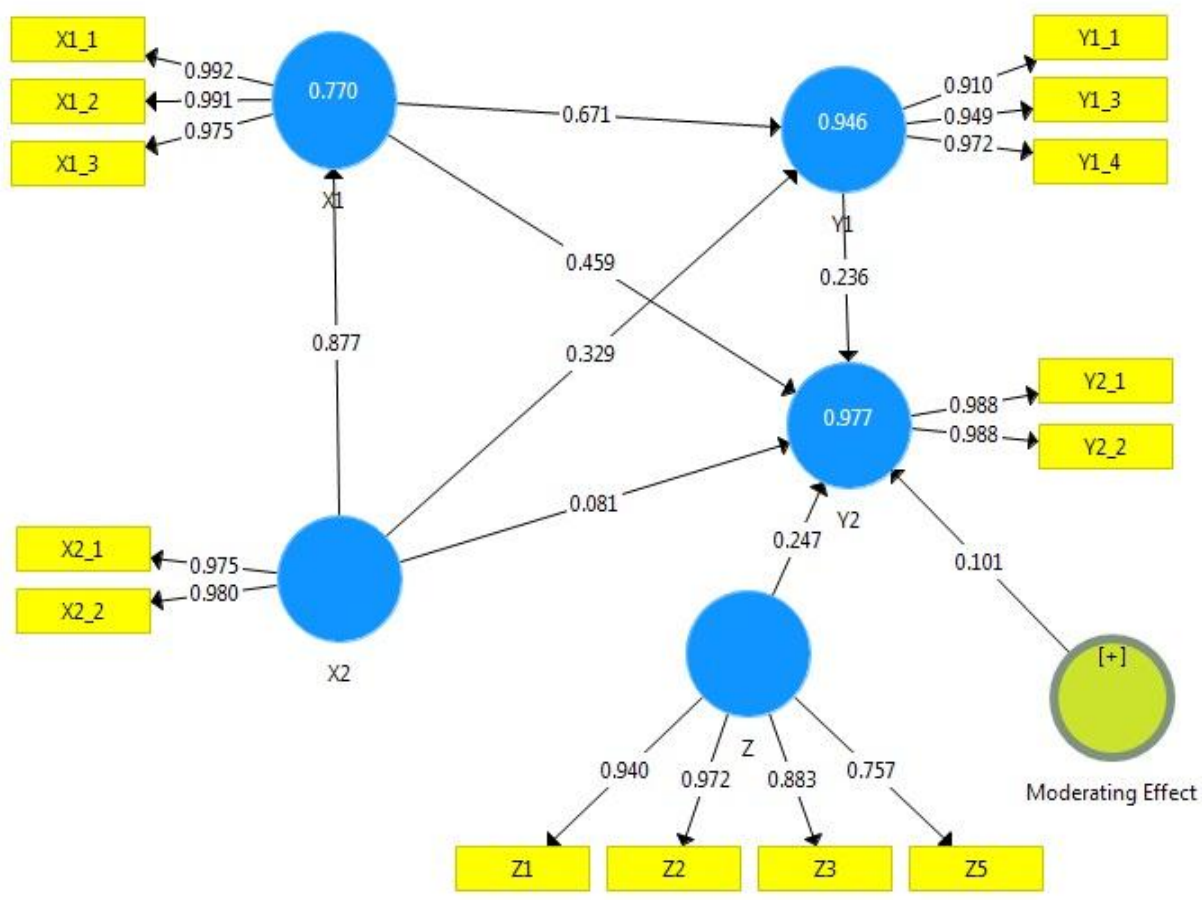

\section{Gambar 3. Diagram Model Pengaruh Moderasi}

Sementara itu, jika melihat gambar di atas, output olah data dengan bantuan SmartPLS versi 3.0, dapat disajikan lebih rinci pada Tabel 10. sebagai berikut:

Tabel 10.

Uji Pengaruh Moderasi Pengalaman Kerja

\begin{tabular}{cccccc}
\hline $\begin{array}{c}\text { Hubungan } \\
\text { Moderasi }\end{array}$ & $\begin{array}{c}\text { Original Sample } \\
(\boldsymbol{O})\end{array}$ & $\begin{array}{c}\text { Standard } \\
\text { Deviation } \\
(\text { STDEV })\end{array}$ & $\begin{array}{c}\text { T Statistik } \\
(\mid \boldsymbol{O} / \text { STDEV } \mid)\end{array}$ & P Values & Keterangan \\
\hline $\mathrm{X} 2 * \mathrm{Z}>\mathrm{Y} 2$ & 0,101 & 0,030 & 3,432 & 0,001 & Signifikan \\
\hline Sumber: Data diolah, 2017 & & & &
\end{tabular}

Data pada tabel di atas menunjukkan bahwa ada pengaruh pendidikan terhadap produktivitas yang dimoderasi oleh pengalaman kerja sebesar 0,101 dan t-statistik 3,432 serta p-values 0,001. Artinya, pengaruh pengalaman kerja dalam memoderasi pengaruh pendidikan terhadap produktivitas. Penelitian Kotur (2014); Lailah (2014); Widowati dan Mokhlas (2015); dan Wasasih (2016) memiliki 
pandangan yang sama bahwa pendidikan tidak memiliki pengaruh terhadap produktivitas, melainkan pendidikan akan diperkuat oleh keterampilan dan pengalaman. Sedangkan, menurut penelitian Swart (2010) berpendapat bahwa produktivitas kerja dipengaruhi oleh aspek pengalaman kerja. Sehingga dengan demikian dapat disimpulkan bahwa, pengalaman kerja pada penelitian ini berfungsi sebagai variabel moderasi (memperkuat) pengaruh pendidikan terhadap produktivitas kerja wartawan di Provinsi Bali.

\section{SIMPULAN DAN SARAN}

Berdasarkan hasil analisis data dan pembahasan maka penelitian ini dapat disimpulkan sebagai berikut: (1) Konpensasi dan Pendidikan berpengaruh terhadap Program Kesejahteraan Wartawan di Provinsi Bali. (2) Kompensasi, Pengalaman Kerja dan Program Kesejahteraan berpengaruh terhadap Produktivitas Kerja Wartawan di Provinsi Bali. Sementara pendidikan tidak memiliki hubungan pengaruh terhadap produktivitas kerja Wartawan di Provinsi Bali. (3) Pendidikan mempunyai pengaruh terhadap kompensasi Wartawan di Provinsi Bali. (4) Pendidikan mempunyai pengaruh terhadap Program Kesejahteraan melalui Kompensasi Wartawan di Provinsi Bali. (5) Kompensasi dan Pendidikan memiliki hubungan yang positif dan signifikan terhadap Produktivitas Kerja melalui Program Kesejahteraan Wartawan di Provinsi Bali. (6) Pengelaman Kerja memiliki hubungan memoderasi antara hubungan pengaruh Pendidikan terhadap Produktivitas Kerja Wartawan di Provinsi Bali. 
Berdasarkan hasil penelitian dan simpulan maka saran yang dapat diberikan adalah perusahaan media yang ada di Provinsi Bali hendaknya memperhatikan program kesejahteraan karyawannya. Perusahaan media yang ada di Provinsi Bali hendaknya memperhatikan kompensasi, pengalaman kerja, pendidikan dan program kesejahteraan karyawan untuk meningkatkan produktivitas kerja. Perusahaan media yang ada di Provinsi Bali juga perlu memperhatikan pengalaman kerja calon pegawai baru pada saat pelaksanaan rekrutmen. Saran untuk pemerintah, khususnya Dinas Tenaga Kerja Provinsi Bali mengawasi secara ketat perusahaan media yang ada di Bali untuk menjalankan keputusan dan peraturan pengupahan daerah, sehingga tidak ada lagi wartawan yang menerima kompensasi atau balas jasa di bawah standar Upah Minimum Provinsi (UMP) yang telah ditentukan. Selain itu, hasil penelitian ini membuka peluang bagi peneliti selanjutnya untuk menelaah dan menggali variabel-variabel lainnya yang diduga berpengaruh terhadap produktivitas kerja.

\section{REFERENSI}

Ajala, Emmanuel Majekodunmi. 2012. The Influence of Workplace Environment On Workers' Welfare, Performance And Productivity. Journal of the African Educational Research Network, (ISSN\# TX 6-342-323)). Africa: University Of Ibadan.

Aliansi Jurnalis Independen (AJI) Denpasar. 2015. Data Anggota Wartawan AJI Tahun 2015. Tidak Diterbitkan.

Anggraini, Nita. 2012. "Hubungan Kausalitas Dari Tingkat Pendidikan, Pendapatan, Dan Konsumsi Terhadap Jumlah Penduduk Miskin Di Provinsi Jawa Tengah".

Anoraga, Pandji. 1997. Manajemen Bisnis. Jakarta: Rineka Cipta. 
Balaji, C. 2013. Implications of Employee Welfare and Rewards on Job Satisfaction and Productivity - An Insight. GRA International - Global Research Analysis International Journal, Vol 2 Issue 2 (ISSN No 2277 8160).

Dewan Pers Nasional. 2015. Data Pers Nasional 2015, Mengambangkan Kemerdekaan Pers dan Meningkatkan Kehidupan Pers Nasional. Jakarta: Dewan Pers.

Draf, Richard L. 2000. Manajemen Edisi Kelima. Jilid Satu. Jakarta: Erlangga.

Ghozali dan Fuad. 2005. Struktural Equation Modeling; Teori, Kosep, dan Aplikasi dengan program Lisrel 8.54. Semarang: BP UNDIP.

Ghozali, Imam. 2011. Aplikasi Analisis Multivariate Dengan Program IBM SPSS 19. Semarang: Universitas Diponogoro.

Hui Min, Cynthia. NG, et al. 2012. The Association Between Employee Welfare And Job Motivation: A Study On Malaysian Tertiary Education Institutions. Malaysia: Journal Of University Tunku Abdul Rahman.

Idris, Irwandi \& dkk. 2007. Membangun Raksasa Ekonomi: Sebuah Kajian Terhadap Perundang-undangan Pengelolaan Wilayah Pesisir dan Pulaupulau Kecil. Bogor: Penerbit Buku Ilmiah Populer.

Jianhong, Wang and Jiansuo, Ma. 2010. Influence of Compensation on Loyalty to Organization. PR. China: Journal Of Hebei Institute of Architecture and Civil Engineering.

Jogiyanto. 2007. Metodologi Penelitian Bisnis: Salah Kaprah dan Pengalamanpengalaman. (Cetakan pertama). Yogyakarta: BPFE.

Lailah, Isnainiyah. 2014. Pengaruh Pengalaman Kerja Terhadap Produktivitas Kerja (Studi Kasus pada Tenaga Kerja Langsung Bagian Sortasi (Sortir) di PT Mangli Djaja Raja Kabupaten Jember). Jember: Journal University of Jember.

LeGrain, Philippe. 2003. "Worried Workers: Why Globalisation is Actually the Least of Their Worries?", dalam Open World: The Truth About Globalisation, Ivan R. Dee Incoorporated, pp. 25-46.

Lestariningsih, Daru. 2007. Pengaruh Dividend Payout Ratio, Current Ratio, dan Variance of Earnings Growth Terhadap Price Earnings Ratio Pada Perusahaan Manufaktur Yang Terdapat Di Bursa Efek Indonesia. Semarang: Jurnal Ekonomi Keuangan, Universitas Negeri Semarang.

Maduka, Chukwuna E. 2014. Effect of Motivation on Employee Productivity: A Study of Manufacturing Companies in Nnewi 2 (7) P:137-147. International Journal of Managerial Studies and Research (IJMSR). 
[Online]. Tersedia di: https://www.arcjournals.org/ [Diakses: 12 September 2016].

Mubasher, Hussain Naqvi Syed. 2013. Job Stress and Employees' Productivity: Case of Azad Kashmir Public Health Sector. UAJK: Interdisciplinary Journal Of Contemporary Research In Business.

Muinah. 2015. Faktor-faktor yang Mempengaruhi Kesejahteraan Rumah Tangga di Kabupaten Sedang Bedagai Dengan Pendekatan Regresi Logistik. Medan: Journal Universitas Sumatra Utara.

Negash, Rijalu et al., 2014. The effect of compensation on employees motivation:In Jimma University academic staf. Ethiopia: Basic Research Journal of Business Management and Accounts ISSN 2315-6899 Vol. 3(2) pp. 17-27 February 2014.

Olufunmilayo, F. Odeku and Kola, O. Odeku. 2014. In Pursuit of the Employees' Welfare in the Workplace: Issues in Perspectives. Mediterranean Journal of Social Sciences, Vol 5 No 15 (ISSN 2039-9340). Rome, Italy: MCSER Publishing.

Padma Dewi, I Gusti Ayu dan Mustika, Made Dwi Setyadhi. 2015. Produktivitas Pekerja Wanita Perajin Tenun Ikat di Kabupaten Klungkung. Jurnal EP Unud, Vol. 4 No. 10: 1304-1327 (ISSN: 2303-0178). Denpasar: Fakultas Ekonomi dan Bisnis Universitas Udayana.

Persatuan Wartawan Indonesia (PWI) Bali. 2015. Data Jumlah Anggota Wartawan. Tidak Diterbitkan.

R. Kotur, Bhargava and Anbazhagan S. 2014. Education and Work-Experience Influence on the Performance. IOSR Journal of Business and Management (IOSR-JBM) e-ISSN: 2278-487X, p-ISSN: 2319-7668. Volume 16, Issue 5. Ver. III (May. 2014), PP 104-110 www.iosrjournals.org.

Ruby, Mensah. 2012. The Impact of Indirect Compensation on Employee Productivity: A Case of Central University College. A Thesis submitted to the Institute of Distance Learning, Kwame Nkrumah University of Science and Technology.

Saputri, Oktaviana Dwi. 2011. Analisis Kesempatan Kerja di Kota Salatiga. Semarang: Jurnal Ekonomi Pembangunan Universitas Diponogoro.

Sastrohadiwiryo, Siswanto. 2005. Manajemen Tenaga Kerja Indonesia (Pendekatan Administratif dan Operasional). Jakarta: Sinar Grafika Offset.

Singh, Sweta. 2015. Effectiveness Of Employee Welfare In Maruti Suzuki In Varanasi Region. Journal of Management Research and Analysis, April June 2015;2(2):150-161. 
Sinungan, Muchdarsyah. 2000. Produktifitas, Apa dan Bagaimana, Edisi Ketiga. Jakarta: Bumi Aksara.

Sugiyono. 2013. Metode Penelitian Bisnis. Cetakan Enam belas. Bandung: CV Alfabeta.

Sukirno, Sadono. 2008. Mikro Ekonomi Teori Pengantar. Jakarta: PT. Raja Grafindo Persada.

Sulaeman, Ardika. 2014. Pengaruh Upah dan Pengalaman Kerja terhadap Produktivitas Karyawan Kerajinan Ukiran Kabupaten Subang, Trikonomika Volume 13, No.1, Hal 91-100 ISSN 1411-514 X (print)/ISSN 23557737 (online).

Swart, R. 2011. The Influence Of Employee Motivation On Productivity In A Merged Real Estate Environment. Mini-dissertation submitted in partial fulfilment of the requirements for the degree Master of Business Administration at the Potchefstroom campus of the North-West University.

Tiwari, Usha. 2014. A Study on Employee Welfare Facilities and Its Impact on Employees Efficiency at Vindha Telelinks Ltd. Rewa (M.P.) India. Abhinav International Monthly Refereed Journal of Research, Volume 3, Issue 11 (ISSN-2320-0073).

Todaro, Michael P and Smith, Stephen. C. 2006, Pembangunan Ekonomi jilid satu, Edisi Kesembilan terjemahan, Jakarta, Penerbit Erlangga.

Undang-Undang Nomor 13 Tahun 2003 tentang Ketenagakerjaan.

Undang-Undang Nomor 3 Tahun 1992 tentang Jaminan Sosial Tenaga Kerja.

Undang-Undang Nomor 40 Tahun 1999 tentang Pers.

Upadhyay, Devina and Gupta, Anu. 2012. Morale, Welfare measures, Job Satisfaction: The Key Mantras for Gaining Competitive Edge. http://www.ijmra.us: International Journal of Physical and Social Sciences Volume 2, Issue 7, ISSN: 2249-5894.

Wasasih, Ni Made. 2016. Pengaruh Pendidikan Pada Kinerja Bendahara Dengan Pelatihan Dan Motivasi Sebagai Pemoderasi. Denpasar: E-Jurnal Ekonomi dan Bisnis Universitas Udayana 5.2 (2016) : 359-386, ISSN : 2337-3067.

Widowati, Maduretno dan Mukhlas. 2015. Model Kepuasan Pelanggan Dengan Pengalaman Kerja Sebagai Variabel Moderating (Studi Pada Rumah Sakit Di Kota Semarang). Jurnal Fokus Ekonomi, Vol. 10 No. 1 pp: 22-43.

Witschge, Tamara and Nygren, Gunnar. 2009. Journalism: A Profession Under Pressure?. Journal of Media Business Studies 6 (1) p: 37-59. 
Yamoah, Emmanuel Erastus. 2013. Relationship Between Compensation And Employee Productivity. Ghana: Singaporean Journal of Business Economics, And Management Studies Vol.2, No.1.

Yanthi, Purnama Cokorda Istri Dian dan Marhaeni, A.A.I.N. 2015. Pengaruh Pendidikan, Tingkat Upah Dan Pengangguran Terhadap Persentase Penduduk Miskin Di Kabupaten/Kota Provinsi Bali. Denpasar: PIRAMIDA Jurnal Kependudukan dan Pengembangan Sumber Daya Manusia Vol. XI No. 02: 68-75, ISSN: 1907-3275.

Yuniarsih, Tjutju dan Suwatno. 2009. Manajemen Sumber Daya Manusia. Bandung: Alfabeta. 